\title{
Occurrence of the fungus Clathrus archeri (Phallaceae) in the Rożnowskie Foothills (Western Carpathians, Poland)
}

\section{Adam Stebel}

Occurrence of the fungus Clathrus archeri (Phallaceae) in the Rożnowskie Foothills (Western Carpathians, Poland). - Acta Mus. Siles. Sci. Natur., 64: 17-19, 2015.

\begin{abstract}
The paper presents the description of the new site of the expanding fungus Clathrus archeri (Berk.) Dring. in the Polish part of the Carpathians.
\end{abstract}

Key words: fungi, alien species, stinkhorn mushrooms, distributional data, Carpathians

\section{Introduction}

Clathrus archeri (Berk.) Dring. is a representative of the family Phallaceae native to Australia, Malay Archipelago, Mauritius, New Zealand, South and East Africa, South America and Tasmania. It was introduced to Europe (first locality La Petite Raon, France) probably with wool or cotton at the beginning of the $20^{\text {th }}$ century and after acclimatization it started to expand in Western and Central Europe (Stengl-Rejthar \& Wojewoda 1984).

In Poland C. archeri was observed for the first time in 1973 in the vicinity of Wzgórza Krzyżowe near of the village Sieniawka in Lower Silesia (Chlebicki 1997). At present, number of its sites in the country is estimated above 90 (Szczepkowski \& Obidziński 2012). First data from the Polish part of the Carpathians (south-eastern slopes of Mt Wielki Rogacz near Piwniczna in the Beskid Sądecki) originate from 1981 (Stengl-Rejthar \& Wojewoda 1984). Currently, this species is known here from scattered sites (Wojewoda 2003; Szczepkowski \& Obidziński 2012).

\section{Description of the new locality}

The new site of Clathrus archeri was found on the Rożnowskie Foothills near the settlement Olszowa-Podlesie on the western slope of Mt Styr; altitude $356 \mathrm{~m}$; GPS coordinates 4948'33.9"N, 2048'18.4"E, ATPOL grid square EF 96 (Fig. 1). Nine fruit bodies of C. archeri (Fig. 3) occurred at margin of disused meadow overgrown by Solidago gigantea and young Betula pendula forest (Fig. 2).

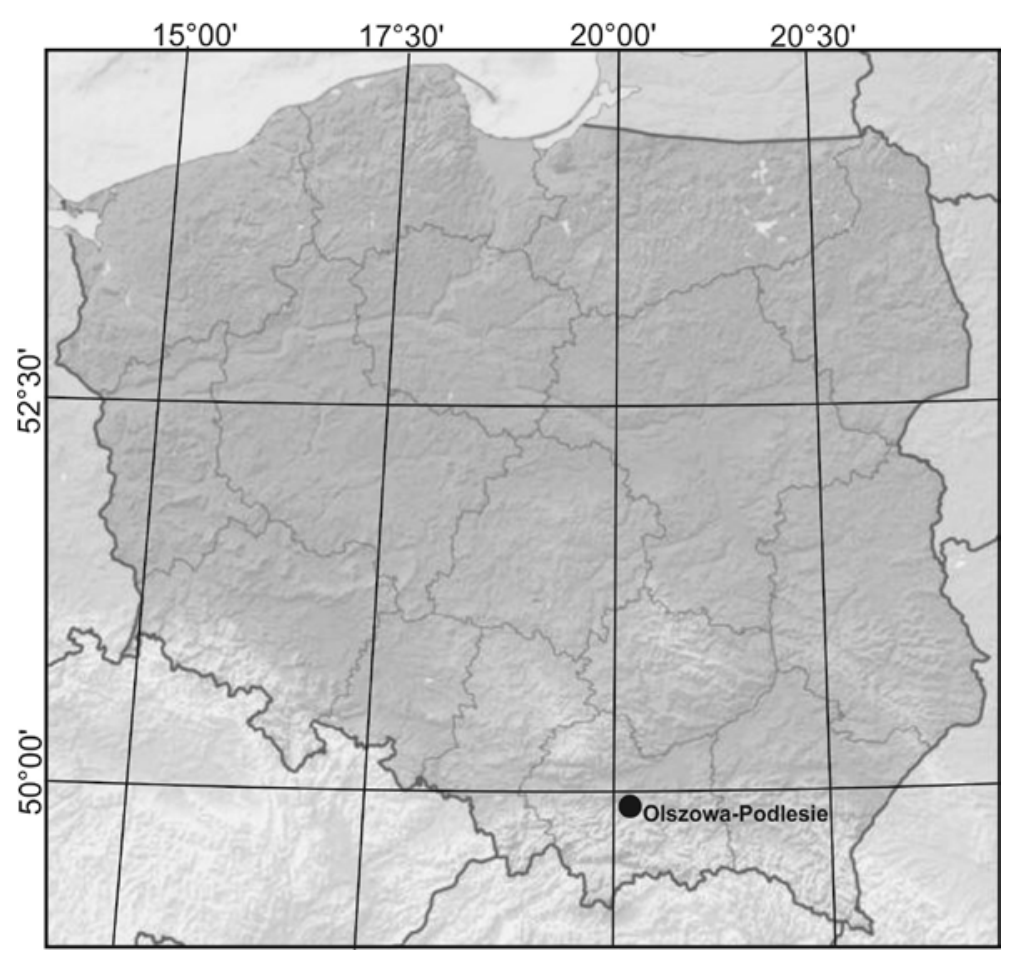

Fig 1: New site of Clathrus archeri in Poland. 


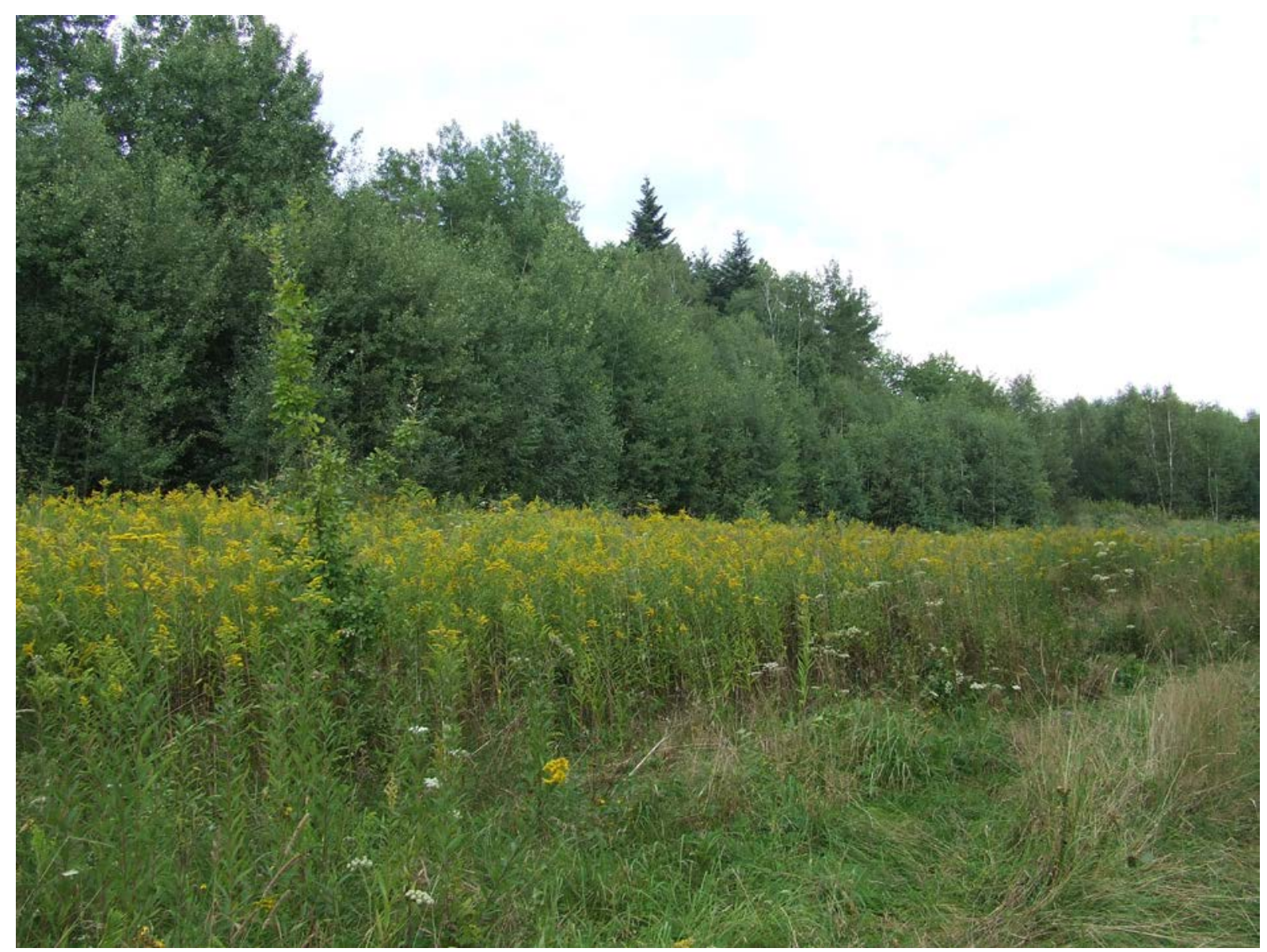

Fig 2: General view on site of Clathrus archeri (Photo by A. Stebel, 17 August 2014).

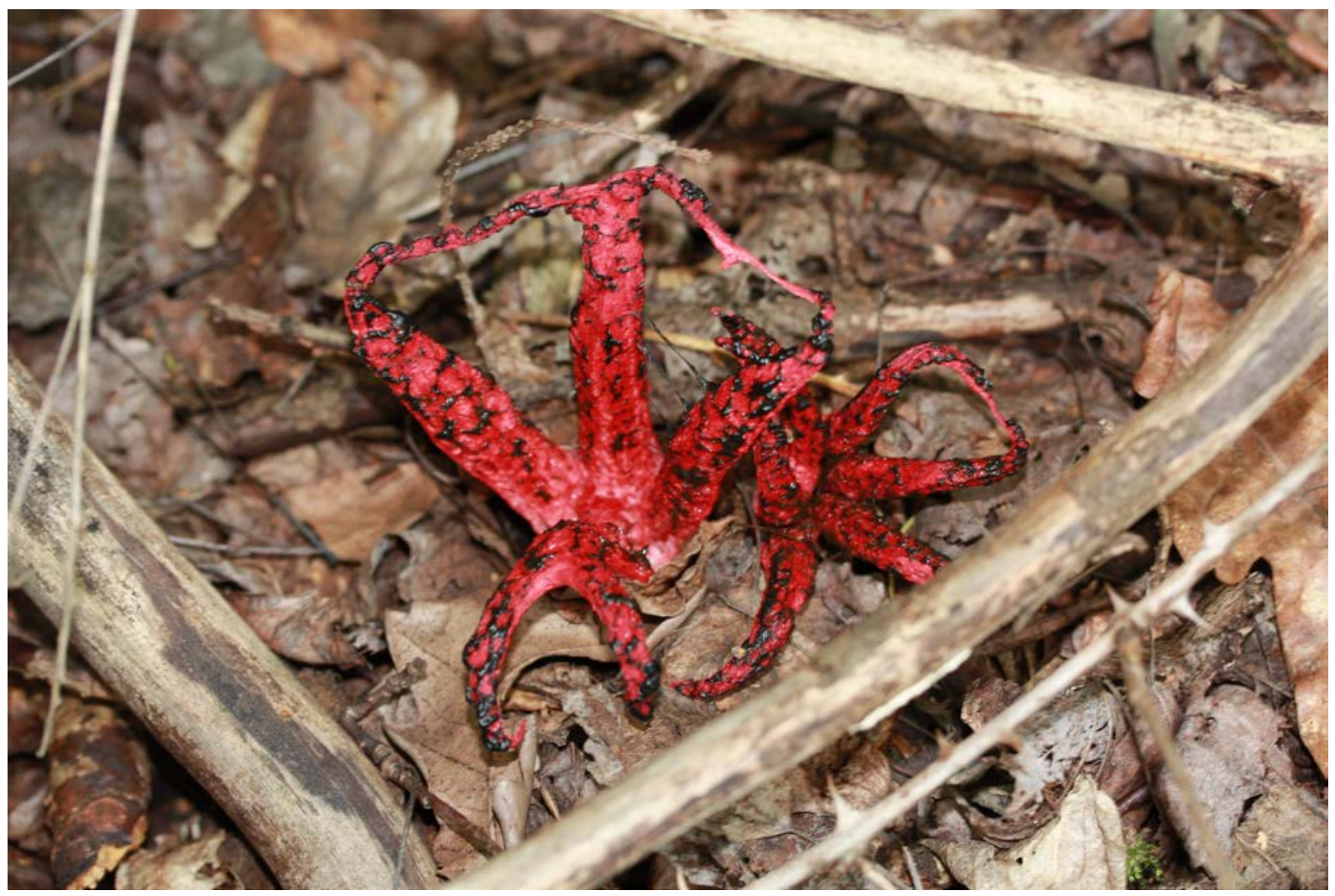

Fig 3: Fruit body of Clathrus archeri (Photo by A. Stebel, 17 August 2014). 


\section{Discussion}

Clathrus archeri is a species, which relatively not long ago appeared in Poland, but in the recent years the number of its localities has quickly increased and currently it is estimated over 90. As in other members of the family Phallaceae, it is characterized by wide habitat range, thus it can inhabit various plant communities, both natural and anthropogenic (Szczepkowski \& Obidziński 2012). On the Rożnowskie Foothills this species was reported from Sucha Góra (Trzeciak 2000), a place located about $10 \mathrm{~km}$ towards east from newly found site in Olszowa-Podlesie. Taking into consideration diversity of habitats of the area, discovery of next sites of $C$. archeri in the near future is highly probable.

\section{References}

Chlebicki A. (1997): Nowe stanowiska smardzówki czeskiej Verpa bohemica, okratka australijskiego Clathrus archeri i czasznicy olbrzymiej Calvatia gigantea na Dolnym Śląsku. - Chrońmy Przyrodę Ojczystą 53(1): 104-110.

Stengl-Rejthar A. \& Wojewoda W. (1985): Expansion of the fungus Clathrus archeri (Berk.) Dring. (Gasteromycetes) in Europe and Poland. - Zeszyty Naukowe Uniwersytetu Jagiellońskiego 752, Prace Botaniczne 13: 105-110.

Szczepkowski A. \& Obidziński A. (2012): Obce gatunki sromotnikowatych Phallaceae w lasach Polski. - Studia i Materiały CEPL w Rogowie. Zeszyt 33(4): 279-295.

Trzeciak A. (2000): Stanowiska chronionych i rzadkich gatunków grzybów w Ciężkowicko-Rożnowskim Parku Krajobrazowym. - Chrońmy Przyrodę Ojczystą 56(5): 131-133.

Wojewoda W. (2003): Checklist of Polish larger Basidiomycetes. In: Mirek Z. (ed.), Biodiversity of Poland. Vol. 7. W. Szafer Institute of Botany, Polish Academy of Sciences, Kraków.

Author's address: Adam Stebel, Department of Pharmaceutical Botany, School of Pharmacy with Division of Laboratory Medicine, Medical University of Silesia in Katowice, Ostrogórska 30, PL-41-200 Sosnowiec, e-mail: astebel@sum.edu.pl. 